総 説 有機溶剤之その関連物質の定量的構造活性相関

\author{
谷 井 秀 治*
}

\title{
STRUCTURE-ACTIVITY RELATIONSHIPS OF ORGANIC SOLVENTS AND RELATED CHEMICALS
}

\author{
Hideji TANII
}

The number of chemicals used in industry is increasing, and as a consequence workers in chemical industries are thought to have many opportunities for being exposed to chemicals. For organic solvents, although a number of studies have shown the toxicity of individual chemicals, there are a relatively small number of studies that have described their toxicity in terms of a quantitative structure-activity relationship (QSAR). In the present article I first introduced an outline of the method of QSAR (Hansch's method), and then reviewed the literature on QSAR of industrial chemicals, principally organic solvents and related chemicals as follows:

1) A review was made of the studies of general toxicity of chlorophenols, alcohols, amines, anilines, phenols, ethers, alkanes, ketones, acrylates, methacrylates and nitriles. In almost all cases, the general toxicity is related to $\log P$, in which $P$ is $n$-octanol/water partition coefficient, indicating the importance of the hydrophobicity of chemicals for their toxicities.

2) The QSARs of anesthetic organic solvents were reviewed. The chemicals analysed were ethers, alkanes, ketones, miscellaneous chemicals and anesthetic gases. It is shown that the relative anesthetic potency of anesthetic gases depends not only on the hydrophobicity expressed by $\log P$ but on a polar factor, while the potency of other chemicals depends largely on $\log P$.

3) The relationship of the structure of organic solvents to skin penetration or absorption was reviewed. QSARs reveal that the potency of skin penetration or absorption of solvents is a function of water solubility, $\log P$ or hydrogen bond number, each relating to hydrophobicity.

4) Some organic solvents have an effect on the upper respiratory tract. The established QSAR models considerably resemble corresponding equations for gas/liquid partition coefficients into organic bases such as tricresylphosphate.

5) The ecotoxicity of chemicals including solvents was reviewed. Overall, the relative toxic potency of chemicals is related linearly to $\log P$, indicating the importance of hydrophobicity in determining the toxicity of chemicals.

6) Although no QSAR has modeled the mutagenic activity of organic solvents, a few studies show the relationship between the structure and mutagenicity of haloalkenes. Finally, if QSAR could model the toxicity of a series of chemicals, it would serve our purpose of understanding the mechanism of toxicity and of predicting the toxic potency of chemicals in the same series tested.

Key words : quantitative structure-activity relationship; organic solvents; general toxicity ; anesthetic property; skin toxicity; sensory irritation; ecotoxicity; mutagenicity

\section{I.はじめに}

産業衛生学で扱ら物質の種類と数は膨大なるのとなっ ている.これは産業的には有用でありながら，人間に有

* 金沢大学医学部衛生学教室

平成 6 年 1 月 24 日受付

* Department of Hygiene, School of Medicine, Kanazawa University

Received for publication, January 24, 1994
害な作用を示すことが多いことに起因している，物質が もつこの有害な作用を研究する毒性学では一方では，毒 性物質を作用物質として考光，毒作用にいたる作用機序 を解明することによって逆に生体機能を明らかにする基 礎科学的研究が可能である. 他方では，毒性物質の中毒 予防・管理，許容濃度の設定など社会的ニーズに応える ための応用科学的研究も必要である.このように毒性学 は非常に守備範囲が広いと考兵られる. しかる毒性と一 
Table 1. Descriptors for chemical structure.

Physicochemical

1. general

2. hydrophobic

3. electronic

4. quantum chemicalj atomic charge, bond energy, resonance energy, energy of the highest oc-

Steric cupied molecular orbit, energy of the lowest unoccupied molecular orbit, electron density

melting point, boiling point, vapor pressure, dissociation constant, activation energy, heat of reaction, reaction rate constant, oxidation potential partition coefficient, solubility in water, parachor, chromatographic hydrophobic parameter

Hammett constant, substitution constant, ionization potential, hydrogen bond, dielectric constant, dipole moment

electron density

molar volume, molar refraction, Taft's steric parameter, Hancock's steric parameter, sterimol parameter
ロに言っても，急性あるいは慢性毒性，神経毒性，発がん 性, 催奇形性, 繁殖毒性, 刺激性, 変異原性, 細胞毒性, 生態毒性など多岐にわたっているリので，個々の物質で あってもその毒性の全体像を解明するのは困難なるのと なっている.ところで数ある毒性のなかである特定のも のに着目し，毒性物質を化学構造上関連性のあるるのに 限定すれば（とさには関連性のないるのる含める)，毒性 と化学構造との間に一定の関連性が導かれるはずであ り，この仮説が成立すれば種々の物質について書性と化 学構造との関係を定量的に記述することが可能となる。

定量的構造活性相関 (Quantitative structure-activity relationship, QSAR) 法はもともと医薬品や農薬の研究 で用いられていた方法で, 近年フメリカで Hanschや Free らが数式モデルを尊入して以来大いに進歩し た2,3. 一方，QSAR 法に対して定性的構造活性相関法 あある.例えば, $n$-ヘキサンの神経毒性研究から明らか になったよらに，最終的に生体内で $\gamma$-ジケトンに変化 する有機化合物が神経毒性を示すことを解明した研 究4 7 は有機溶剂の毒性学でのよい例である. しかしな がら，この ケージケトン仮説は，nーヘキサンやその関連 化合物の神経毒性の研究の結果として導きだされたもの であり, 研究の企画の段階から化学構造と毒性との関係 を意図していた訳ではない，対照的に，研究企画の段階 で化学物質の構造と活性（毒性）との相関を求めようと するのが QSAR 法である.この QSAR 法は既に毒性 学研究の方法諭として少しずつ応用されてきている. 本 論文ではまず QSAR 法の概略を示すが，更に詳しい解

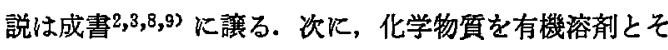
の関連物質に絞り，種々の毒性への QSAR 法の最近の
応用例を概観し，その中で毒性物質の作用機序解明や毒 性予測にとって QSAR 法が有效であることを示してみ たい.

\section{QSAR の構成要素}

QSAR 法は化学構造記述子，生物活性及び相関を求 めるための手法から構成される.

\section{1. 化学構造記述子}

化学構造記述子とは分子の特性またはその物理化学的 性質のことであり，Table 1 に示すように実に多くの記 述子が用いられている，分類すると大きく二つに分けら れる. 一つは物理化学的性質であり，その中には一般 的, 蹯水的, 電子的, 量子化学的各性質が含まれる. 他 の一つは立体的性質を表わするのである. 本論文では扱 わないので Table 1 には載せていないが，三番目に分類 される構造記述子がある. それには分子の部分構造, 環 の数, 分岐の程度などが含まれる.

\section{2. 生物活性}

QSAR 法では研究者の目的によって生物活珄が選ば れる. 生物活性には一次的影響 (生化学的 end point) から二次的影響（毒性学的影響の観察）まで含まれる. しかも，一般的に化学構造記述子に比ぺて生物活性の測 定精度ははるかに低いことが特徵となっている。

\section{3. 相関を求めるための手法}

1) Hansch の手法8)

化学物質の生物活性はその化学物質の柾水性，電子的 珄質，及び立体的珄質に大きく依存すると考え，各性質 を表わすバラメータの関数であると仮定する. 一般式は 次のいずれかの式で表わされる. 
$\log B A=a(\log P)^{2}+b \log P+c \sigma+d E_{\mathrm{s}}+e$

$\log B A=a \pi^{2}+b \pi+c \sigma+d E_{\mathrm{s}}+e$

$B A$ : 種々の眉換基 $\mathrm{X}$ を持つある系列の化合物 $\mathrm{RX} の$ メンバーの生物活性

$\log P: \log$ （オクタノール/水分配係数）

$\pi:$ 疎水的パラメータ

$\sigma$ : 電子的パラメータ

$E_{\mathrm{s}}$ : 立体的パラィータ

$a \sim e:$ 回誉分析によって求められる定数

回㷌式の適合度は相関係数 $(r)$, 標準誤差 $(S)$ ，及び

$F$ 值によって表わされる.ここで $F$ 值は $F_{n-m-1}^{m}=\left\{r^{2} /\right.$ $\left.\left(1-r^{2}\right)\right\} \times(n-m-1) / m$ で定義され， $n$ は観測数， $m$ は独立変数の数を示守.

まず眯水的性質の特徽についてであるが，QSAR 洗を 用いた研究の初期では物質の柾水性を各種の有機溶媒/ 水分配係数として表わしていたが，多くの研究の結果， オクタノール/水分配係数 $(P)$ 方最を QSAR に適して いることが現在判明している10,11). 即ち，後述の例でる 明らかなよらに, $\log P$ を用いた QSAR の成功例が非常 に多い，その理由は $\log P$ のつ生物学的意義に求めら れて扣り，一つはオクタノールが他の生体成分と適度に 水素結合できること，他の一つは， $\log P$ が化学物質の 作用部位への輸送及び化学物質と作用部位との間の柾水 的相互作用と関連している12)ことが QSAR に有利に働 くよらである.このよらに $\log P$ の重要性が認められ， 更に $\log P$ から置換基定数 $\pi$ が導かれて次のように定義 される18.

$$
\pi \mathrm{X}=\log P_{\mathrm{RX}}-\log P_{\mathrm{RH}}
$$

$\mathrm{RX}$ : 置換基 $\mathrm{X}$ をつむる化合物

$\mathrm{RH}$ : 置換基Xを持たない（Xを水素で置換）化合物 例光ぱメチル基の $\pi$ 值は次のよらに定義される.

$$
\pi \text { チル }=\log P_{\text {トルェンー }} \log P_{\text {ベンゼン }}
$$

このよらにして得られた各種置換基の $\pi$ 値は数多く知 られ，成司2,93 に一覧表として载せてある，代表的な固 換基の $\pi$ 值を Table 2 に示す、トルエンの $\log P$ を知り たいときは,

$$
\begin{aligned}
\log P_{\text {トルメン }} & =\log P \text { ヘンザン十 } \pi \text { メチル } \\
& =2.69+0.56 \\
& =3.25
\end{aligned}
$$

のよらに計算できる.

化学物質が毒性学的影響を発現するとき，最終的には 既知あるいは未知の受容体との反応が重要であるが，化 学物質の輸送過程と柾水的相互作用を表現している $\log$

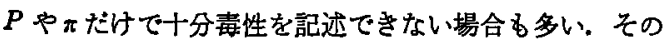
際，電子的相互作用や立体效果を表すバンータ
(Table 1) が用いられ，その種類は多い、これらのパラ メータの意羲と概略については成書2,8》に詳しく述ぺら れている. 後述の QSAR 適用例の中で若干紹介してみ たい.

2）その他の方法

Free-Wilson 法, 因子分析法, 最短距雌法などが使用 されているが，後述の適用例では Hansch 法に中心をお

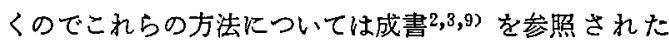
w.

\section{III. 毒性学での QSAR 適用}

各適用例は Table 3 にまとめてある.この表で，r， Sが空欄のところがあるが，文献に記戴のないことによ る. $n$ は分析に用いた化合物の数，rは相関係数， $S$ は 標準誤差を示す。

\section{1. 一般毒性}

クロロフェノール類の培羑細胞への毒性（LC50）は Eq. 1 に示されるように $\log D$ と $\sigma$ に比例する. ここ で $\log D=\log P-\log \left[1+\right.$ anti $\left.\log \left(\mathrm{pH}-\mathrm{p} K_{\mathrm{a}}\right)\right]$ であり, Dをイオン化と中性分子を考慮した分布係数といら，。 は Hammett の置換基定数である.クロロフェノール類 の毒性は，その蹯水性とミトコンドリアを含めた膜での プロトン透過性を高める性質により決定されることが推 定されている.

Dillingham ら ${ }^{15)}$ はアルコール類 $(n=15)$ の $\mathrm{ID}_{50}$ $\left(=\log 1 / \mathrm{ID}_{50}\right)$ と $\mathrm{pH}_{50}\left(=\log 1 / \mathrm{H}_{50}\right)$ の変動が Taft $の$ 立体置換基定数 $E_{\mathrm{s}}\left(\mathrm{R}_{2}\right)$ で各々 $65 \%$ (Eq. 2) 及び 68 $\%$ (Eq. 3) 説明されることを示した. ここで $\mathrm{ID}_{50}$ は細 胞の成長を $50 \%$ 阻害するアルコールの濃度, $\mathrm{H}_{50}$ はウ サギの赤血球の $50 \%$ に溶血をひきおこすアルコールの 濃度である. 全 15 物質のうち, 脂肪族アルコールに限 れば， $\mathrm{ID}_{50}$ と $\mathrm{pH}_{50}$ は Eq. 4 と5 で示されいずれの 生物活性も全変動の $98 \%$ が説明される. しかし残りの ハロゲン化フルコール $(n=7)$ については QSAR は不 十分であった，彼らは他に第 1 ，第 2 アルコール，第 1 八ロゲン化アルコール等に分けて分析しているが，理想 的には全アルコールを一のの式で表現できた方がよいと 思われる.このことは後述の例ですいえることである が，扱っている物質を分けて分析せざるを得ない場合る あるが，別々に分析する背景には物質を分けている因子 が潜んでいる可能性が存在するからである.

Yano ら ${ }^{162}$ は脂肪族アミンの培養線維芽細胞に対する QSAR を調べた. 疎水性パラメータとして,よく用いら れるフラスコ平衡法 (Flask-shaking 法) ではなく，高 性能薄層クロマトグラフィーの $R_{\mathrm{M}}\left(=\log \left(1 / R_{\mathrm{f}}-1\right)\right.$ ， 
Table 2. Values for $\pi$.

\begin{tabular}{|c|c|c|c|}
\hline Function & $\pi$ & Function & $\pi$ \\
\hline $\mathrm{B}(\mathrm{OH})_{2}$ & -0.55 & 4-Pyridyl & 0.32 \\
\hline $\mathrm{H}$ & 0.00 & $\mathrm{CH}=\mathrm{CHCO}_{2} \mathrm{C}_{2} \mathrm{H}_{5}$ & 0.86 \\
\hline $\mathrm{Br}$ & 0.86 & Cyclopentyl & 2.14 \\
\hline $\mathrm{CF}_{3}$ & 0.88 & $\left(\mathrm{CH}_{2}\right)_{3} \mathrm{~N}\left(\mathrm{CH}_{3}\right)_{2}$ & 0.60 \\
\hline $\mathrm{CN}$ & -0.57 & $\mathrm{C}_{6} \mathrm{H}_{5}$ & 1.96 \\
\hline COO- & -4.36 & Cyclohexyl & 2.51 \\
\hline $\mathrm{CHO}$ & -0.65 & $\left(\mathrm{CH}_{2}\right)_{3} \mathrm{~N}\left(\mathrm{CH}_{3}\right)_{3}+$ & -4.15 \\
\hline $\mathrm{COOH}$ & -0.32 & $\mathrm{C}=\mathrm{O}\left(\mathrm{C}_{6} \mathrm{H}_{5}\right)$ & 1.05 \\
\hline $\mathrm{CH}_{2} \mathrm{Br}$ & 0.79 & $\mathrm{CH}=\mathrm{NC}_{6} \mathrm{H}_{5}$ & -0.29 \\
\hline $\mathrm{CH}_{2} \mathrm{Cl}$ & 0.17 & $\mathrm{CH}_{2} \mathrm{C}_{6} \mathrm{H}_{5}$ & 2.01 \\
\hline $\mathrm{CONH}_{2}$ & -1.49 & $\mathrm{CH}(\mathrm{OH}) \mathrm{C}_{6} \mathrm{H}_{5}$ & 0.54 \\
\hline $\mathrm{CH}=\mathrm{NOH}$ & -0.38 & $\mathrm{CH}_{2} \mathrm{CH}_{2} \mathrm{C}_{6} \mathrm{H}_{5}$ & 2.66 \\
\hline $\mathrm{C}=\mathrm{O}(\mathrm{NHOH})$ & -1.87 & $\mathrm{CH}=\mathrm{CHCOC} \mathrm{H}_{5}$ & 0.95 \\
\hline $\mathrm{CH}_{3}$ & 0.56 & $\mathrm{~F}$ & 0.14 \\
\hline $\mathrm{CH}_{2} \mathrm{OH}$ & -1.03 & $\mathrm{Cl}$ & 0.71 \\
\hline $\mathrm{CH}_{2} \mathrm{NH}_{2}$ & -1.04 & I & 1.12 \\
\hline $\mathrm{C}=\mathrm{O}\left(\mathrm{CF}_{3}\right)$ & 0.02 & IO & -3.74 \\
\hline $\mathrm{C} \equiv \mathrm{CH}$ & 0.40 & $\mathrm{IO}_{2}$ & -3.46 \\
\hline $\mathrm{CH}_{2} \mathrm{CN}$ & -0.57 & NO & -0.12 \\
\hline $\mathrm{CH}=\mathrm{CHNO}_{2}($ trans $)$ & 0.11 & $\mathrm{NO}_{2}$ & -0.28 \\
\hline $\mathrm{CH}=\mathrm{CH}_{2}$ & 0.82 & $\mathrm{NH}_{2}$ & -1.23 \\
\hline $\mathrm{COCH}_{3}$ & -0.55 & $\mathrm{NHOH}$ & -1.34 \\
\hline $\mathrm{CO}_{2} \mathrm{CH}_{3}$ & -0.01 & $\mathrm{NHNH}_{2}$ & -0.88 \\
\hline $\mathrm{CH}_{2} \mathrm{COOH}$ & -0.72 & $\mathrm{NHSO}_{2} \mathrm{NHSO}_{2} \mathrm{NH}_{2}$ & -2.11 \\
\hline $\mathrm{C}=\mathrm{O}\left(\mathrm{NHCH}_{3}\right)$ & -1.27 & 5-Cl-1-tetrazolyl & -0.65 \\
\hline $\mathrm{CH}_{2} \mathrm{CONH}_{2}$ & -1.68 & $\mathrm{~N}=\mathrm{CCl}_{2}$ & 0.41 \\
\hline $\mathrm{C}_{2} \mathrm{H}_{5}$ & 1.02 & $\mathrm{~N}=\mathrm{C}=\mathrm{S}$ & 1.15 \\
\hline $\mathrm{CH}=\mathrm{CHCN}$ & -0.17 & 1-Tetrazolyl & -1.04 \\
\hline $\mathrm{CH}=\mathrm{CHCOOH}$ & 0.00 & NHCHO & -0.98 \\
\hline $\mathrm{CH}_{2} \mathrm{CH}=\mathrm{CH}_{2}$ & 1.10 & $\mathrm{NHCONH}_{2}$ & -1.30 \\
\hline $\mathrm{CH}_{2} \mathrm{COCH}_{3}$ & -0.69 & $\mathrm{NHCSNH}_{2}$ & -1.40 \\
\hline $\mathrm{CH}_{2} \mathrm{OC}=\mathrm{O}\left(\mathrm{CH}_{3}\right)$ & -0.17 & $\mathrm{NHCH}_{3}$ & -0.47 \\
\hline $\mathrm{CH}_{2} \mathrm{CH}_{2} \mathrm{CO}_{2} \mathrm{H}$ & -0.29 & $\mathrm{NHSO}_{2} \mathrm{CH}_{3}$ & -1.18 \\
\hline $3,4-\left(\mathrm{CH}_{2} \mathrm{CH}_{2} \mathrm{CH}_{2}\right)$ & 1.20 & $\mathrm{NHCOCF}_{3}$ & 0.08 \\
\hline $\mathrm{CH}_{2} \mathrm{CH}\left(\mathrm{NH}_{3}{ }^{+}\right) \mathrm{COO}-$ & -3.56 & $\mathrm{NHCOCH}_{3}$ & -0.97 \\
\hline $\mathrm{C}_{3} \mathrm{H}_{7}$ & 1.55 & $\mathrm{NHC}_{2} \mathrm{H}_{5}$ & 0.08 \\
\hline $\mathrm{CH}\left(\mathrm{CH}_{3}\right)_{2}$ & 1.53 & $\mathrm{~N}\left(\mathrm{CH}_{3}\right)_{2}$ & 0.18 \\
\hline $\mathrm{CH}_{2} \mathrm{~N}\left(\mathrm{CH}_{3}\right)_{2}$ & -0.15 & $\mathrm{~N}\left(\mathrm{SO}_{2} \mathrm{CH}_{3}\right)_{2}$ & -1.51 \\
\hline 2-Thienyl & 1.61 & $\mathrm{~N}=\mathrm{NN}\left(\mathrm{CH}_{3}\right)_{2}$ & 0.46 \\
\hline $3,4-(\mathrm{CH}=\mathrm{CHCH}=\mathrm{CH})$ & 1.32 & $\mathrm{NHCOC}_{2} \mathrm{H}_{5}$ & -0.47 \\
\hline $\mathrm{CH}=\mathrm{CHCOCH}_{3}$ & -0.06 & $\mathrm{NHCO}_{2} \mathrm{C}_{2} \mathrm{H}_{5}$ & 0.17 \\
\hline $\mathrm{C}\left(\mathrm{CH}_{3}\right)_{3}$ & 1.98 & $\mathrm{~N}\left(\mathrm{CH}_{3}\right)_{3}{ }^{+}$ & -5.96 \\
\hline
\end{tabular}


Table 2. (continued)

\begin{tabular}{|c|c|c|c|}
\hline Function & $\pi$ & Function & $\pi$ \\
\hline $\mathrm{NHC}_{4} \mathrm{H}_{9}$ & 1.45 & $\mathrm{OCH}_{2} \mathrm{CON}(\mathrm{Me})_{2}$ & -1.36 \\
\hline $\mathrm{N}=\mathrm{NC}_{6} \mathrm{H}_{5}$ & 1.69 & $\mathrm{OCH}_{2} \mathrm{CON}\left(\mathrm{CH}_{2} \mathrm{CH}_{2}\right)_{2} \mathrm{O}$ & -1.39 \\
\hline $\mathrm{NHC}_{6} \mathrm{H}_{5}$ & 1.37 & $\mathrm{OCH}_{2} \mathrm{CONHC}_{6} \mathrm{H}_{5}$ & 0.60 \\
\hline $\mathrm{NHSO}_{2} \mathrm{C}_{6} \mathrm{H}_{5}$ & 0.45 & $\mathrm{OCH}_{2} \mathrm{CON}(\mathrm{Me}) \mathrm{C}_{6} \mathrm{H}_{5}$ & 0.12 \\
\hline $\mathrm{N}=\mathrm{CHC}_{6} \mathrm{H}_{5}$ & -0.29 & $\mathrm{SO}_{2} \mathrm{~N}(\mathrm{Me})_{2}$ & -0.78 \\
\hline $\mathrm{NHCOC}_{6} \mathrm{H}_{5}$ & 0.49 & $\mathrm{OCH}_{2} \mathrm{CO}-c-\mathrm{NC}_{5} \mathrm{H}_{10}$ & -0.32 \\
\hline $\mathrm{O}^{-}$ & -3.87 & $2-\mathrm{C}_{5} \mathrm{H}_{4} \mathrm{~N}$ & 0.50 \\
\hline $\mathrm{OH}$ & -0.67 & $\mathrm{NHC}(=\mathrm{S}) \mathrm{NHCHCH}_{2} \mathrm{CH}_{3}$ & 0.71 \\
\hline $\mathrm{OCF}_{3}$ & 1.04 & $\mathrm{CH}=\mathrm{NNHCONH}$ & -0.85 \\
\hline $\mathrm{OCONH}_{2}$ & -1.05 & $\mathrm{CH}=\mathrm{NNHCOC} \mathrm{H}_{5}$ & 0.43 \\
\hline $3,4-\left(\mathrm{OCH}_{2} \mathrm{O}\right)$ & -0.05 & $\mathrm{CH}=\mathrm{NNHCSNH}_{2}$ & -0.27 \\
\hline $\mathrm{OCH}_{3}$ & -0.02 & $\mathrm{CH}=\mathrm{NNHSO} \mathrm{O}_{2} \mathrm{Me}$ & -0.93 \\
\hline $\mathrm{OSO}_{2} \mathrm{CH}_{3}$ & -0.88 & $\mathrm{CH}=\mathrm{NN}\left(\mathrm{CH}_{2}\right)_{5}$ & 0.91 \\
\hline $\mathrm{OCOCH}_{3}$ & -0.64 & $\mathrm{CH}=\mathrm{NNHCONHNH}_{2}$ & -1.32 \\
\hline $\mathrm{OCH}_{2} \mathrm{COOH}$ & -0.87 & $\mathrm{NHCOCH}_{2} \mathrm{Cl}$ & -0.50 \\
\hline $\mathrm{OC}_{2} \mathrm{H}_{5}$ & 0.38 & $\mathrm{H} \mathrm{N}-$ & \\
\hline $\mathrm{OC}_{3} \mathrm{H}_{7}$ & 1.05 & $1 y$ & -0.25 \\
\hline $\mathrm{OC}_{6} \mathrm{H}_{5}$ & 2.08 & $-N$ & \\
\hline $\mathrm{OSO}_{2} \mathrm{C}_{6} \mathrm{H}_{5}$ & 0.93 & $-12=$ & 0.95 \\
\hline $\mathrm{OCOC}_{6} \mathrm{H}_{5}$ & 1.46 & $c-\mathrm{N}\left(\mathrm{CH}_{2} \mathrm{CH}_{2}\right)_{2} \mathrm{O}$ & -0.77 \\
\hline $\mathrm{SO}_{2}(\mathrm{~F})$ & 0.05 & $\mathrm{NHCH}_{2} \mathrm{C}_{6} \mathrm{H}_{5}$ & 1.00 \\
\hline $\mathrm{SF}_{5}$ & 1.23 & $\mathrm{~N}=\mathrm{NN}(\mathrm{Me}) \mathrm{COMe}$ & 0.54 \\
\hline $\mathrm{SO}_{3}^{-}$ & -4.76 & $\mathrm{OCH}_{2} \mathrm{C}_{6} \mathrm{H}_{5}$ & 1.66 \\
\hline $\mathrm{SH}$ & 0.39 & $\mathrm{CSNH}_{2}$ & -0.64 \\
\hline $\mathrm{SO}_{2}\left(\mathrm{NH}_{2}\right)$ & -1.82 & $\mathrm{CONHNH}_{2}$ & -1.92 \\
\hline $\mathrm{SCCl}_{3}$ & 1.65 & $\mathrm{CH}=\mathrm{NOCH}_{3}$ & 0.40 \\
\hline $\mathrm{SO}_{2}\left(\mathrm{CF}_{3}\right)$ & 0.55 & $c-\mathrm{C}_{3} \mathrm{H}_{5}$ & 1.14 \\
\hline $\mathrm{SCF}_{3}$ & 1.44 & $\mathrm{CH}_{2} \mathrm{OC}_{6} \mathrm{H}_{5}$ & 1.66 \\
\hline SCN & 0.41 & $\mathrm{CH}=\mathrm{C}(\mathrm{CN})_{2}$ & 0.05 \\
\hline $\mathrm{SOCH}_{3}$ & -1.58 & $-\mathrm{C}\left(\mathrm{NH}_{2}\right)=\mathrm{NH}_{2}+\mathrm{Cl}^{-}$ & -3.72 \\
\hline $\mathrm{SO}_{2} \mathrm{CH}_{3}$ & -1.63 & $\mathrm{CH}_{2} \mathrm{OCH}_{3}$ & -0.78 \\
\hline $\mathrm{SCH}_{3}$ & 0.61 & $\mathrm{C} \equiv \mathrm{CC}_{6} \mathrm{H}_{5}$ & 2.65 \\
\hline $\mathrm{SCOCH}_{3}$ & 0.10 & $\mathrm{NHC}(=\mathrm{O}) \mathrm{CH}(\mathrm{Me})_{2}$ & -0.18 \\
\hline $\mathrm{SC}_{2} \mathrm{H}_{5}$ & 1.07 & $\mathrm{OC}(=\mathrm{O}) \mathrm{C}_{6} \mathrm{H}_{5}$ & 1.46 \\
\hline $\mathrm{SO}_{2}\left(\mathrm{C}_{6} \mathrm{H}_{5}\right)$ & 0.27 & $\mathrm{COOC}_{6} \mathrm{H}_{5}$ & 1.46 \\
\hline $\mathrm{SC}_{6} \mathrm{H}_{5}$ & 2.32 & $\mathrm{C}(\mathrm{OH})\left(\mathrm{CF}_{3}\right)_{2}$ & 1.28 \\
\hline $\mathrm{SeCH}_{3}$ & 0.74 & $\mathrm{P}(=\mathrm{O})(\mathrm{OMe})_{2}$ & -1.18 \\
\hline $\mathrm{Si}\left(\mathrm{CH}_{3}\right)_{3}$ & 2.59 & $\mathrm{CH}=\mathrm{CHC}_{6} \mathrm{H}_{5}$ (trans) & 2.68 \\
\hline$c-\mathrm{C}_{5} \mathrm{H}_{10} \mathrm{~N}-$ & 0.65 & $\begin{array}{l}n-\mathrm{C}_{4} \mathrm{H}_{9} \\
3-\mathrm{NHC}(=\mathrm{O})-\mathrm{C}_{5} \mathrm{H}_{4} \mathrm{~N}\end{array}$ & $\begin{array}{r}2.13 \\
-0.40\end{array}$ \\
\hline $\mathrm{OCH}_{2} \mathrm{CONH}_{2}$ & -1.37 & NHCN & -0.26 \\
\hline
\end{tabular}

The $\pi$ values were cited from the literature. ${ }^{2)}$ 


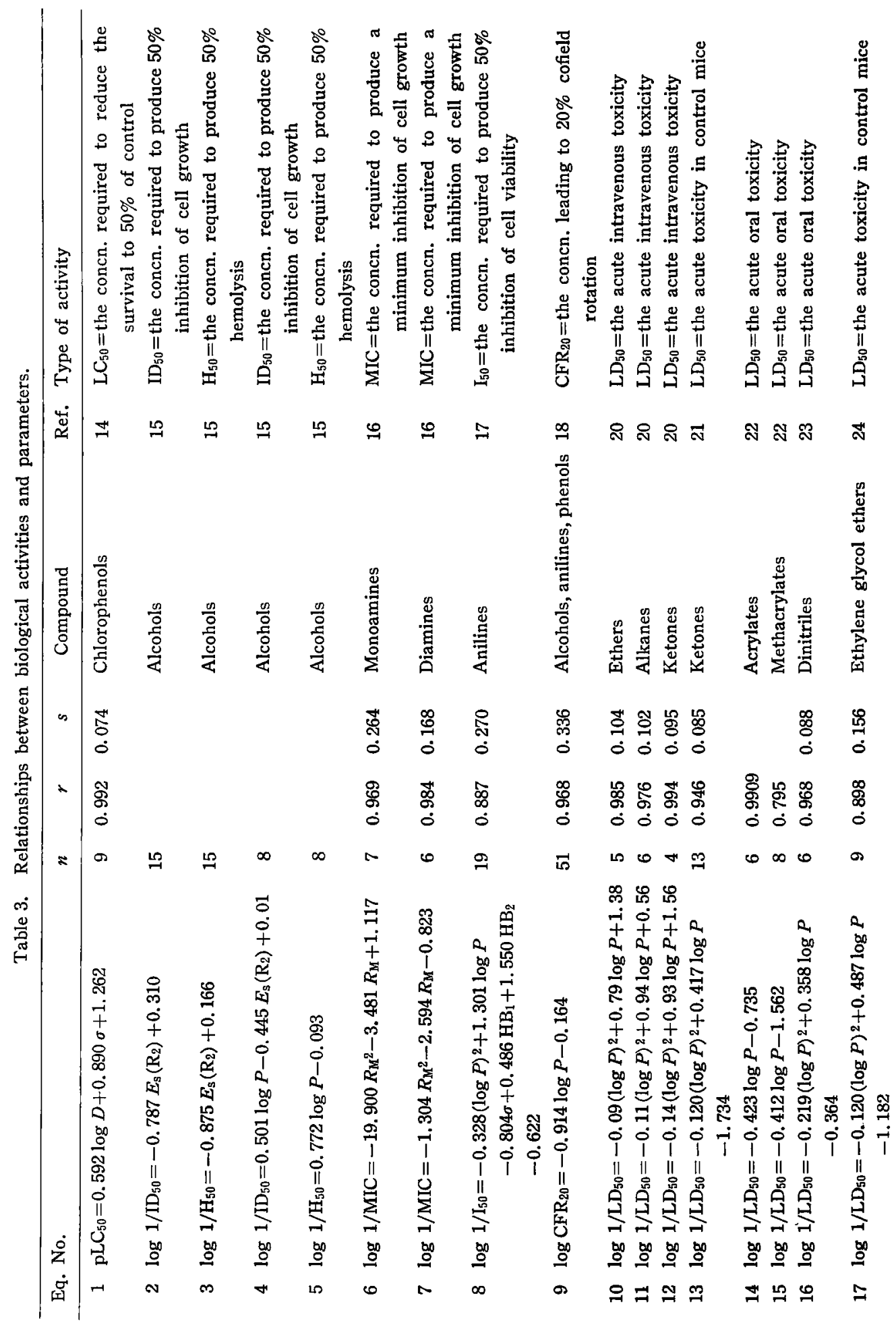



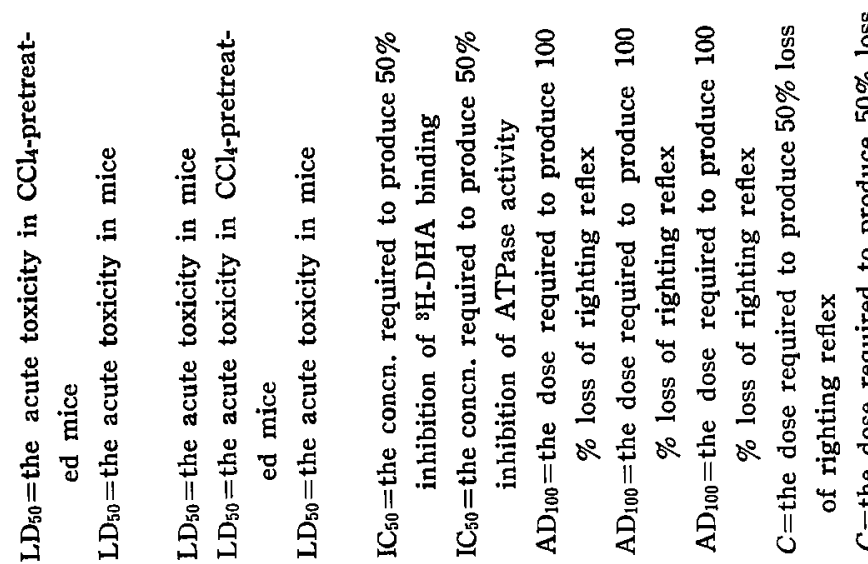

ส
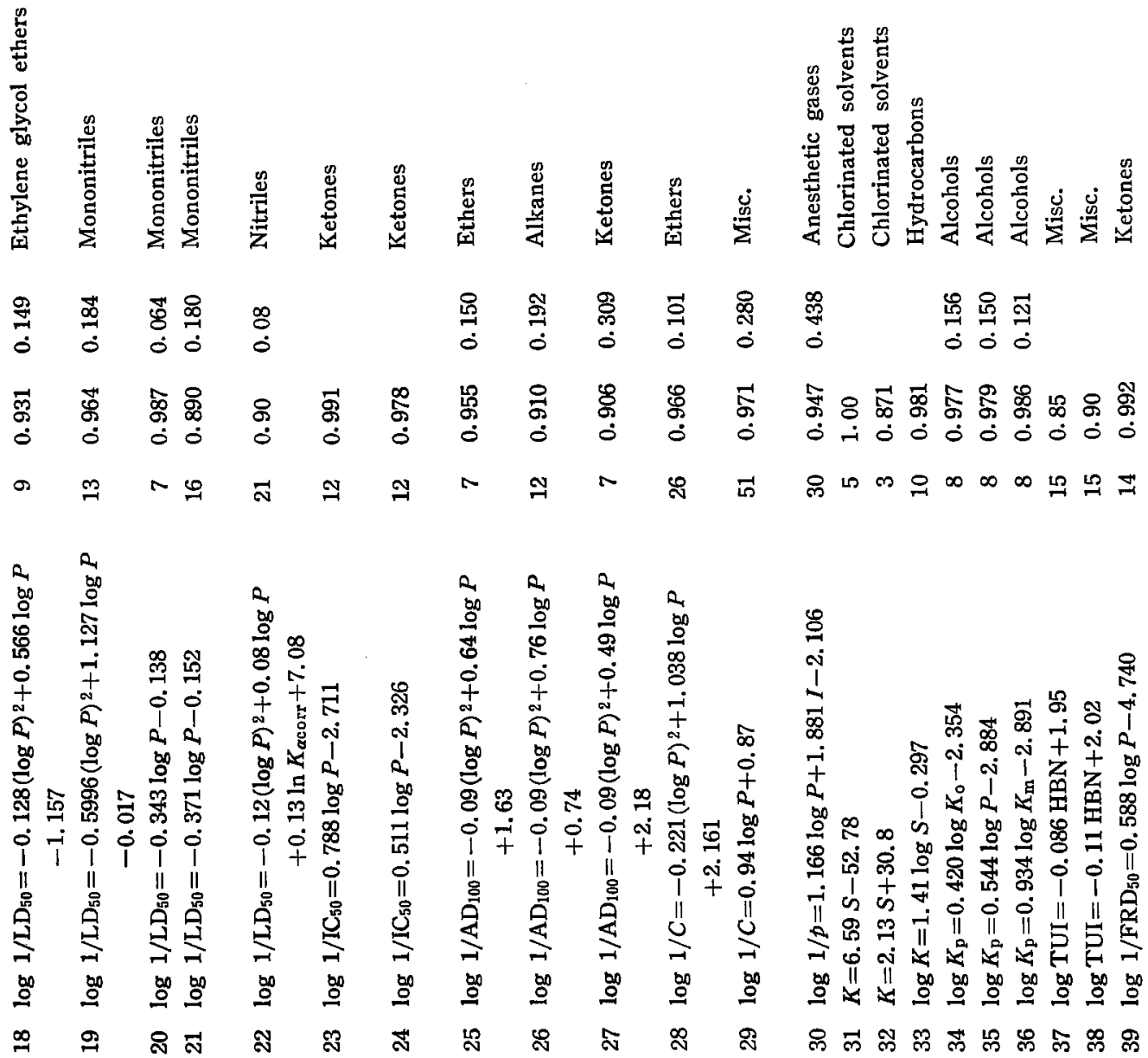

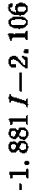

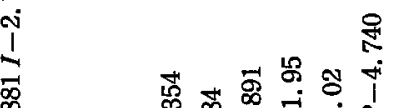

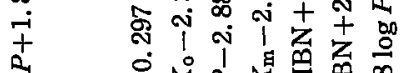

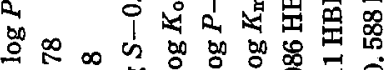
\&

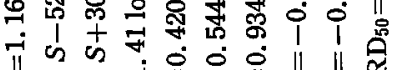

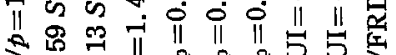

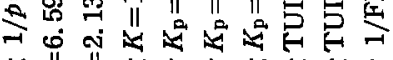

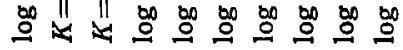

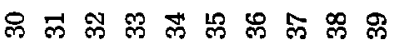




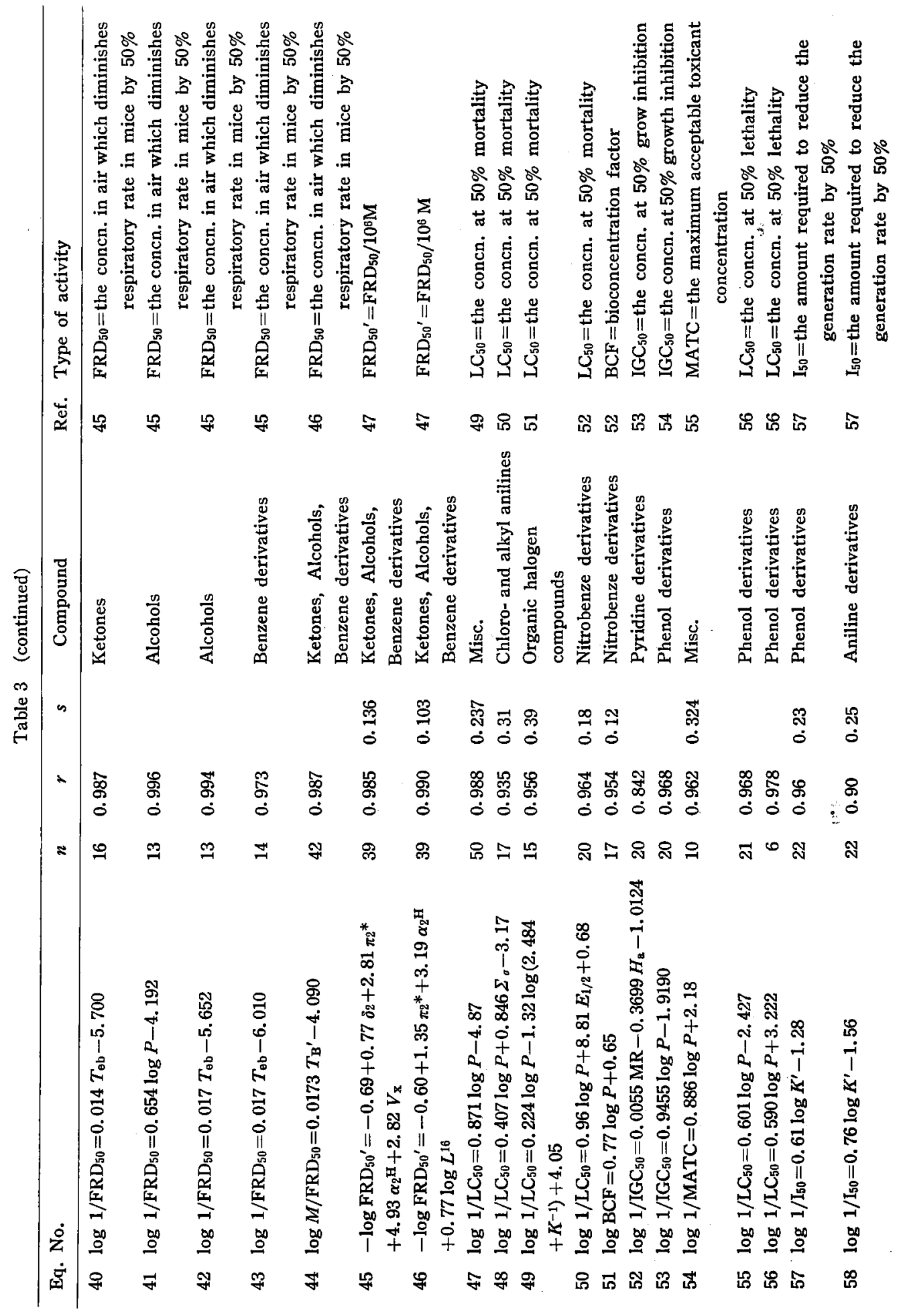




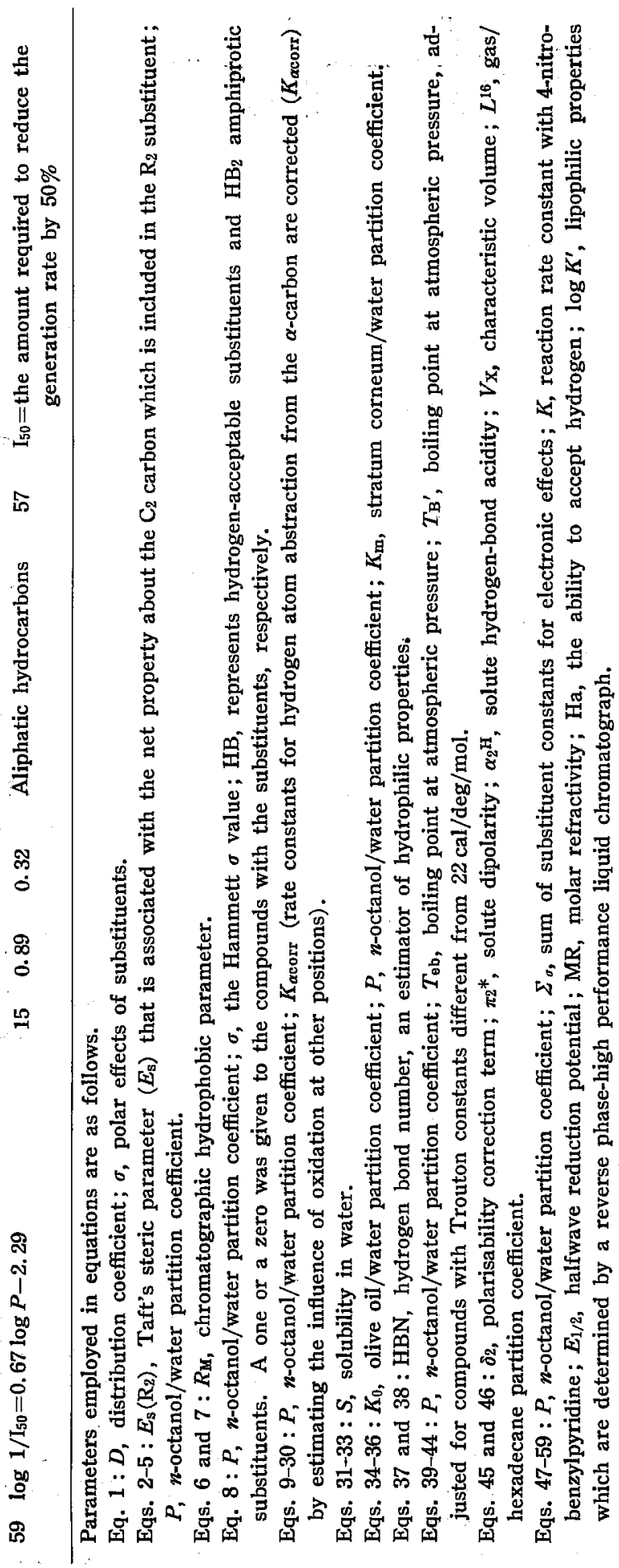




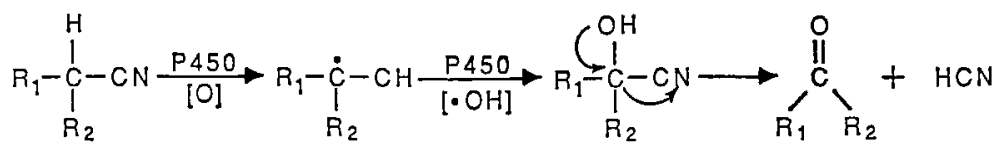

$R_{1}=R_{2}, H$, alkl or aryl

Fig. 1. Cytochrome $\mathrm{P} 450$ mediated cyanide release from nitriles.

$R_{\mathrm{f}}$ は溶質の移動比）を使い，モノアミンでは Eq. 6 を シフミンでは Eq. 7 を得た。 $R_{M}$ と $P$ との間には， $R_{M}$ $=a \log P+b$ が成立することが知られている2. $\log P$ を 測定するのは時に岋困難を伴うので，比較的簡便に測定 できる各種クロマトグラフィーから得られる眯水性パラ メータをQSAR に使用することは従来から行われてお

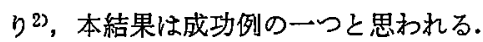

アニリン誘導体の培羡線維芽細胞に対する QSAR は 脂肪族フミンのそれよりもやや複雑で, Eq. 8 とな $る^{17)}$. 説明変数として $\log P$ に加えて, Hammett の $\sigma$, 及びダミ一变数の $\mathrm{HB}_{1}\left(-\mathrm{NO}_{2}\right.$ や $-\mathrm{OCH}_{3}$ のよ 5 な

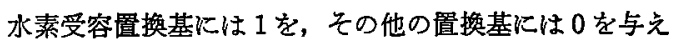
る）と $\mathrm{HB}_{2}\left(-\mathrm{OH} や-\mathrm{NH}_{2}\right.$ のよ5な水素受容と供与 の両性質を示す置換基には 1 を，その他の置換基には0 を与える) が導入されている。このQSAR から， $\log P$ は輸送過程に関与し, $\mathrm{HB}_{1}$ より $\mathrm{HB}_{2}$ の奇与が大きいこ とからアニリン類の作用部位では二つの相互作用が考え られている. 一つは $-\mathrm{NH}_{2}$ の坬立電子対を通しての電 子受容部位との作用, 他の一つは水素受容あるいは供与 のできる部位と置換基との作用である．この仮説をより 確実にするためには更に化合物の数を増やして分析する 必要がある.

Pauli ら ${ }^{18)}$ はフルニール類, フニリン類, フェノール 類の QSAR を調へ， Eq. 9 を得た. 生物活性は培養細 胞の cofield rotation $(300 \mathrm{kHz}$ の回転電場での細胞の 回転) で表している. 細胞の回転数の增加は細胞の膜透 過性の增加に比例するので，上記 3 種類の化合物群の膜 障害性は $\log P$ に上り決定されることを示している.

実験動物を用いた毒性試験は高価なこと, 時間がかか ること，加充て欧米での実験動物を少なくする風潮か ら，代替法としての培養細胞使用の有用性を検討した報 告がある ${ }^{199}$ 。四種の cell lines（細胞系統）に対するフ ルコール類, フェノール類, トルェン類, ジニトロトル エン類の細胞毒性を調べ, 前 3 種類 (フルコール類, フ ェノール類, 及びトルェン類）の毒珄は $\log P$ と直線関 倸になる，即ら化合物の疎水性が高くなると毒性は強く なること, 更にこの関倸はin vivoでの関係に類似して
いることを示している. ジニトロトルエン類の毒性は $\log P$ で説明されていない.

エーテル類, アルカン類, ケトン類のマウスでの急性 毒性は, Eq. 10 13 で示されるよらに $\log P$ の二次関 数である. Eq. 12 と 13 の恙は, 静脈内之経口投与, 、 ウスの系統の差, 分析に用いた化合物の差に由来すると 思われる。

アクリル酸誘導体とメタアクリル酸誘導体の急性毒性 は $\log P$ の一次関数として表わされる (Eq. 14，15). 理想的には化合物を二つに分けずに，一つの式で表現で きるよらに更に工夫が必要とされるだろう.

シニトリル類, エチレングリコールエーテル類, モ, ニトリル類の急性書性はいずれる $\log P$ の二次関数であ る (Eq. 16 19). いずれの化合物の急性毒性る輸送過 程と作用部位での蹯水的相互作用で説明される. Eq. 17 と Eq. 18 の羑は動物の代謝条件の差であるが，両式に 有意差はないので，本エステル類の急性毒性に代謝活性 化は関与していないことになる.

モノニトリル類の急性毒性は, 遊離シフンが原因で 性を発現するニトリルについては $\log P$ の二次関数 (Eq. 19) として, 生体内でシフンを汪とんど遊離しな いニトリルについては $\log P$ の一次関数 (Eq. 20) とし て表される. 四塩化炭素処理マウスでのニトリル類の急 性毒性は $\log P$ の一次関数 (Eq. 21)として表わされ る.この場合, ニトリル類を 2 種類に分けて分析してい るが, 分けないで一つの式として QSAR を表現する方 が望ましい。そこで Grogan ら27は Fig.1 に示す反 応を考皃た，投与されたニトリルは肝の P450によって まず $\alpha$ 炭素（シアンの結合している炭素）に結合してい る水素が引きぬかれ，シフンヒドリンが形成される. 次 に分子内転位が起こってシフンを遊離するが、彼らはこ の反応速度はシフンが結合している炭素骨格の影響を受 けると考克てこれを計算で求的た（反応速度定数 $K_{\alpha \mathrm{corr}}$ ). この反応速度定数と $\log P$ を説明变数として ニトリル類の急性毒性は Eq. 22 として表わされ，より よいQSAR モデルが得られた.

Huang ら ${ }^{28)}$ はケトン類の神経毒性に注目し，その眯 
水性との関係を調べた. マウス緢から得たシナプトソー

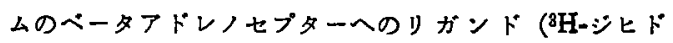
ロフルプレノロール) 結合阻害度と $\mathrm{Na}^{+} / \mathrm{K}^{+}-\mathrm{ATP}$ ァーヒ 活珄阻害度はいずれる $\log P$ の一次関数で (Eq. 23, 24), 膜障害性と踝水性の強い相関が示された。多分他 の有機溶剤にる同様の QSAR か゚成立するであろらから その比較をすることは有機溶剂の神経毒珄を評価する一 助になると思われる。

以上述べてきた通り，有機溶昘及びその関連化合物の 毒性発現に関しては, 全体的にみて $\log P$ の寄与が大き い.このことは有機溶剤に限ったことではなく，広く有 機化合物一般にいえることはHansch と Dunn の研 究11,29)からも判明している.

\section{2. 麻势作用}

有機溶剤の中には麻酔作用を示するのがかなりある。 マウスを用いた QSAR では Eq. 25〜28 にみられるよ 5に, ェーテル類, フルカン類, ケトン類の麻酷作用は $\log P$ の二次関数として表される. Eq. 25 と 28 の羑は $\mathrm{AD}_{100}$ (100\% の動物に麻酔作用を示す化合物の濃度) と $\mathrm{AD}_{50}$ (50\% の動物に麻酔作用を示す化合物の濃度)の 違いと分析に用いたェーテルの数の違いによるるのであ ろらが，一般に $n$ が大きい汪ど回㷌式の信頼度が高いか ら Eq. 28 の方がよりよい式である. Eq. 28 から $\log P_{0}$ (最大麻酔作用を与える $\log P$ の值) は 2.35 と計算さ れるが，この值は重要である，それはこれまで発見され ている多くの麻醉薬の $\log P$ は約 2.0 であるからで， 例えばトリクロロエチレンの $\log P$ は 2.29, メトキシ フラレンは2.21,クロロホルムは1.97，八ロタンは1.81 である ${ }^{300}$. 促って $\log P_{0}=2.35$ を与える Eq. 28 は妥 当な QSAR モデルと思われる.一方，麻醉活性をオタマ ジャクシを用いて測定すると，それは $\log P$ の一次関数 として表わされる (Eq. 29). 類似の系ですやはり $\log P$ の一次関数として表わされていで11)，その特徵は $\log P$ の回㷌係数が約 1.0 といらことにある. Eq. $28 の \log P$ の係数 1.038 はほぼ 1 に近いので, この式の意味は, Eq. 29 にみれるような単純な系に, 更にエーテルの中 枢神経系への輸送過程を表すために $(\log P)^{2}$ 項が加え られたと考えられる。

麻䣲ガスの QSAR が Hansch ら22)により調べられ た (Eq. 30).ここでIはダミ一変数で, polar hydrogen atom (極性水䒺原子) を含む化合物には $I=1$ を与 之，その他の化合物には $I=0$ を与える. 本式から麻醉 ガスの活性には $\log P$ に加えて polar hydrogen atom の存在が大きく影響する (polar hydrogen atom が存在 すれば活性は強くなることになる。
麻酔活性に関する Eq. 25 30 について全体的にい方 ることは，麻醉作用が起こるときには化合物の眯水性が 重要であるが，極性因子す神経機能を傷害するときには 重要な役割を果たしていることである.

Franks と Lieb ${ }^{33)}$ はアルコール類とケトン類を含む 種々の化合物の麻酔活性と植物油/水， $n$-へキサデカン/ 水, $n$ オクタノール/水系での分配係数との関俰を調べ, 極性溶媒である 直線関倸を得て, 麻酔研究での $\log P$ の有用性を示した. Janoff ら ${ }^{34)}$ はアルコール類, ケトン類を含む各種の化合 物 $(n=21)$ の麻酔活性がホスファチジルコリン二重層/ 水での分配係数と直線関係になることを示し， $n$ ーオクタ ノール以外に脂質膜の有用性を報告している.

\section{3. 皮店吸収}

有機溶剤の侵入経路としての皮咸に注目した QSAR の報告がある. Tsuruta ${ }^{35}$ ) 塩素系溶㓮の皮店吸収速度 が水への溶解度 (S) に比例することを示した（Eq. 31, 32). ここで Eq. 31 は $S \geq 16 \mathrm{mM}$, Eq. 32 は $S \leq 16$ mM のときに成立する，更に脂肪族及び芳香族炭化水素 の in vitro での $\log$ (皮盧透過速度) が $\log S$ 々有意 の相関を示すことが報告されて战り 36,37 (Eq. 33)，有 機溶凧の水への溶解度の皮店吸収に拈ける重要性が指摘 されている.

一方 $\log P$ の有用性も報告されている. Roberts 540) は,アルコール類やフェノール類で $\log$ (皮膚透過速度) と $\log P$ との間に直線関倸の存在を報告している. Lien と Tong ${ }^{38)}$ はフルコール類のヒト表皮での透過速度 $\left(K_{\mathrm{p}}\right)$ と各種パラメータとの関係を調べた (Eq. 34〜36). 調べたパラメータはオリーブ油/水 $\left(K_{0}\right)$, オクタノ一 ル/水 $(P)$, 角質層/水 $\left(K_{\mathrm{m}}\right)$ の各分配係数で, いずれ の係数を用いても有意の回㷌式が得られている.

アルコールを含む種々の物質の日本住血吸虫でのとり こみ指数 (TUI, tissue uptake index) と水素結合数 (HBN, hydrogen bond number) との間に有意の相関 が報告されている (Eq. 37, 38). Eq. 37 は雄での, Eq. 38 は榫での式で両性に差はない，更に，HBN は 物質の親水性を表わすパラメータなので両式は親水性が 高いほどTUI が減少することを示している，彼らはま たTUI は分子量が 30 350の間では分子量に大きく影 暗されないと述へている. Eq. 33〜38 では各々有意な QSAR が成立しているが， $S, P, \mathrm{HBN}$ を同時に比較し ていないので結論は導けない，つまり $S$ （水への溶解 度)， $P$, HBN 間に相関の存在する可能性があるので, とのパラメータが最も適しているか今後検討してみる必 要があるだろら。 


\section{4. 上気道に対する刺激性}

有機容剂はその物理化学的性質のため揮発性のるのが 多い.人間が揮発した有機溶剂に暴露されると, 眼, 奥, 咽啹が刺激される．特に眼之鼻の刺激は感賞刺激之呼ば れ，三叉神経が媒介する ${ }^{41,422}$ 。従って刺激の程度は刺激 に係方る受容体に物質が吸着される程度及び受容体と物 質の反応性によって決定されると考完られる48).

Nielsen と Alarie44) はベンゼンとアルキルペンゼン の上気道刺激活性を $\mathrm{RD}_{50}$ (呼吸速度を対照の $50 \%$ に抑 制する気中濃度）として求め，定性的にアルキル鎖の炭 素数が多くなる任ど RD50 値が減少することを示した。 同様の研究が定量的に行和れた 年).ケトン類, アルコー ル類、ベンゼン誘導体類の FRD $\mathrm{F}_{50}\left(\mathrm{RD}_{50}\right.$ と同じ）が $\log P$ あるいは $T_{\mathrm{eb}}$ (température d'ébullition, 大気压 での沸点）の一次関数として Eq. 39 43 として表わさ れた. この QSAR の欠点は $\mathrm{FRD}_{50}$ を $\mathrm{mg} / \mathrm{m}^{3}$ 単位と して求めているので相対的比較が正確にできていないこ とに市る。即ち，刺激活性はモル濃度（M）単位でない といけない，更に， $\log P$ と $T_{\mathrm{eb}}$ のどちらを用いたらよ いのかわからない。

Roberts ${ }^{46)}$ はこの点に注目して Eq. 44 を提出した。 刺激活性を $\mathrm{M} / \mathrm{FRD}_{50}$ としてモ儿漕度に， $T_{\mathrm{eb}}$ を $T_{\mathrm{B}}{ }^{\prime}$ に变換した．ここで $T_{\mathrm{B}^{\prime}}=\left(T r \cdot T_{\mathrm{B}} / 22\right)+40(1-T r)$ 22) である. $T_{B}$ (boiling point at atmospheric pressure) は $T_{\mathrm{eb}}$ と同し意味であり, $\operatorname{Tr}$ (Trouton constant）はモル蒸発熱を沸点に関係づける定数である。

Eq. 44 だけでケトン類，フルコール類， ベンゼン誘道 体類をまとめて扱えることおょび毒性予湘が可能なこ とで優れているが，毒性機權に関する情報は与えていな い.

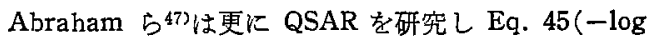
$\mathrm{FRD}_{50}{ }^{\prime}=-0.69+0.77 \delta_{2}+2.81 \pi 2^{*}+4.93 \alpha_{2} \mathrm{H}+2.82$ $\left.V_{\mathrm{x}}\right)$, 及び Eq. $46\left(-\log \mathrm{FRD}_{50}{ }^{\prime}=-0.60+1.35 \pi 2^{*}+\right.$ $\left.3.19 \alpha_{2}{ }^{\mathrm{H}}+0.77 \log L^{16}\right)$ を提出した. ここで $\delta 2$ は分極 率修正項， $\pi 2^{*}$ は二極性， $\alpha_{2}{ }^{\mathrm{H}}$ 付水素結合酸性度， $V_{x}$ は容量， $L^{16}$ は溶質の気 $/ n$ 一ヘキサデカン分配保数を表 す.一方，溶質の気/トリタレシルフォスフェート (TCPH) 分配係数を $L$ とすれば, $\log L(\mathrm{TCPH})=-$ $0.35-0.25 \delta_{2}+1.71 \pi 2^{*}+2.98 \alpha_{2} \mathrm{H}+0.911 \log L^{16}(n=$ $22, r=0.991 ， s=0.09)$ が成立し，この式と Eq. 46 か 類似していることから次のようと考察している．刺激受 容体は適度に極性部位を持ち (Eq. 46 での倸数 1.35 か 5)，水素結合酸性度は有機塩基の tricresylphosphate と同程度である (Eq. 46 での保数 3.19)。しかも受容体 は適度に疎水性を示す (Eq. 46 での㐿数 0.77).この
ようにして QSAR 法を応用することにより感覚刺激受 容体の特性を推定できる.

マウスを用いた $\mathrm{RD}_{50}$ 值は既に 89 物質に対して 154 例（単独と混合曝露を含む）知られていてで8), 許容涶度 (threshold limit values, TLVs) が $0.03 \times \mathrm{RD}_{50}$ とよ い相関 $\left(r^{2}=0.78\right)$ を示すことから，動物実験による $\mathrm{RD}_{50}$ 值の有用性が指摘されている. また； RD 50 亿代わ り得る方法がないのる実情である。

\section{5. 生㠇系への影響}

化学物貿が自然環境に漏出すれば生熊系に影響を与克 るであるち．自然界の生物への影響を QSAR の観点か ら行った研究がある.多くの物質のグッピーへの䓯珄が 調べられ，構造との相関が研究された結果，Eq. 47 が 報告されている49．整くべきことに50 化合物（非反応 性で非イオン性有機化合物) の毒性が $\log P$ 単独で説明 される.これら化合物にはベンゼン，トルエン，フセト ン、エタノール等が含まれる. ただしこの式は $\log P$ <6のときだけにしか成立せず， $\log P>6$ のときは予測 精度は悪くなる.

反応性のアニリン誘道体のグッピーへの毒性は Eq. 48 で示され，Hammett の置换基定数 $\sigma$ が更に必要と なる.

反応性の高いッゲン化合物のグッピーへの毒性は Eq. $49\left(\log 1 / \mathrm{LC}_{50}=0.224 \log P-1.32 \log \left(2.484+K^{-1}\right)\right.$ +4.05) で示される.ここでKは 4-ニトロベンジルピ リジンとの反応速度定数である.

同じくニトロベンゼン類の毒性は Eq. $50\left(\log 1 / \mathrm{LC}_{50}\right.$ $\left.=0.96 \log P+8.81 E_{1 / 2}+0.68\right)$ で示され，ここで $E_{1 / 2}$ (半波還元電位) は化合物 の水素原子火上る還元反応速 度を表す. $\log P$ と $E_{1 / 2}$ の相関が 0.815 と高いにもか かわらず，両者共汇説明変数江用いられているので回㷌 式の意義が小さい，ただし，ニトロベンゼン類のグッピ 一への生物漕縮は $\log P$ 飞比例している(Eq. 51).

テトラヒメナを用いた報告53,54がある，ピリシン誘尊 体とフェノール誘導体の生態毒性は各々 Eq. $52(\log 1)$ IGC $\left._{50}=0.0055 \mathrm{MR}-0.3699 \mathrm{Ha}-1.0124\right)$ 及び Eq. 53 (log $\left.1 / \mathrm{IGC}_{50}=0.9455 \log P-1.9190\right)$ で表わされてい る.ここで MR は分子屈折率を $H_{\mathrm{a}}$ は水素受容能を示 す. 化合物の系列によっては $\mathrm{MR}$ と $\log P$ が高い相関 を示すことが多いが，この報告58) では $\log P$ が検討外 となっている，従って $\log P$ を MR の代わりに使える かもしれない.

Minnow（小淡水魚）を用いそ報告がある 55,56 。。 ケト リ類, ベンゼン類, ニーテル類計 10 化合物の MATC （いかなる毒珄学的影響も与克ない、化合物の”最高濃度） 
は $\log P$ の一次関数として表わされた（Eq. 54).

同様にフェノール類の $\mathrm{LC}_{50}$ \& $\log P$ の一次関数であ るが，より性の弱い化合物は Eq. 55 でこれは極性麻 酔薬の関係式に近いるのであった.より毒性の強いフェ ノール化合物は Eq. 56 で表わされ，これは酸化的リン 酸化の脱共役のモデルとなりらるとしている。

フェノール類, アニリン類, 脂肪族炭化水素類のバク テリア成長阻害度は $\log K^{\prime}$ あるいは $\log P$ に比例する (Eq. 57 59)。ここで $K^{\prime}$ は逆相液体クロマトグラフィ 一により求められる践水性を表わすパラメータで, $\log P$ との相関は高い，電子的及び立体的パラィータも同時に 調べられたが，I50（增殖率を $50 \%$ 抑制する化合物の濃 度）と有意の相関を示さなかったことから柾水性がこれ らの化合物の毒性発現にとって重要である. 全体とし て，ここで报ったほぼすぺての化合物の生態毒性には $\log P$ で表わされる柾水珄が深く係わっていることが明 らかである.

\section{6. 变異原性}

化学物質の变異原性は毒性として重要であり，QSAR の考え方す導入されている. Eder らはアリル化合物と その関連物質の変異原性と化学構 造との相関を調へ た58,59). Ames テストで求めた変異原性 (S9mix の存在 下あるいは非存在下での Salmonella typhimurium に祘 ける復㷌変異ニロニーの数) をてルキル化活性に対して プロットすると，直線部分と非直線部分に分れる，前者 にはアルキル化活性が低い物質から中程度のものまでが 含末れ，後者には強い親電子的化合物即らアルキル化活 性の高いるのが含まれている.フルキル化活性のない物 質には当然ながら変異原性がなかった，更に見方を変兄 ると，直線部分を構成しているのはアリルクロ口化合物 であり，非直線部分は塩素以外の置換基を有するものな ので, QSAR はフリルクロロ化合物についてだけ成功し たといえる。

Jones と Mackrodt はハロアルケンの QSAR を報告 している60,61)。一般的にハロアルケンは代謝されてェポ キサイドに変換後变異原性を示すと考えられるのでエポ キサイドの DNA との反応性が重要である. 一方生体に はクルタチオントランスフェラーゼやエポキシドヒドロ ラーゼのような解毒系も存在するので，エボキサイドの 形成, 反応性, 解毒性のバランスが最も重要と考えられ る. 彼らはハロアルケンから形成されるエポキサイドの 安定性（最も弱いC-O 結合エネルギーを指標としてい る）を分子軦道法で計算し，E. coli $\mathrm{K}_{12}$ での変異出現 率との関係を調べた。 その結果, oxirane ring(一C゙-C 一) の安定性が高すぎても低すぎても変異は出現せず,
中程度の安定度で出現することを示した．このことは前 に述べたバランスを反映していると考えられる．有機 溶剂とその関連物質の変異原性は他の毒性と異なり， Hansch のモデルのように定式化された研究例が見当ら ない、今後更に QSAR を調べる必要がある.

\section{IV. おわりに}

以上, Hansch 法を中心とした QSAR の基本的な構 成とその有機溶剤と関連物質への適用を概観した：毒性 学研究法の一つとして QSAR 法は二つの実際的問題解 決のために評価できるように思われる.一つは化学物質 の生物学的作用機構について情報を与学えことである. 化学物質の作用は基本的にその物理化学的性質に基つい ているはずであるから，数ある性質から作用に結びつく ものを抽出できれば作用機構についての我々の理解む向 上することになる。るう一つは QSAR が確立すれば畫 性の予測が可能となることである. もちろん，Könemann の生熊毒性の QSAR ${ }^{49)}$ にみられるように広範囲 の物質に適用できるが適用物質に制限がつく例が多い。 しかし対象となる物質が化学構造上関連していて，生物 活性が単一で十分明らかにされていれば予測の信頼性は 高くなるだろう．最後に QSAR 法を用いるためには， 毒性学, 生物学, 物理化学, 統計学など多くの知識が要 求される.おそらく各々の專門知識をるつ人との共同研 究によって効率的で信頼度の高いQSAR モデルが導き たせると思われる。

\section{文献}

1) 浦口健二. 萧理学序説. 浦口健二, 上野芳夫, 粕谷 豊, 北川晴雄, 酒井文徳編.トキシコロジー. 東京: 地人書館, $1978: 1-28$.

2) 構造活性相関聯話会, 編. 薬物の構造活性相関. 東京 : 南江堂, 1978.

3）構造活性相関稳話会, 編. 薬物の構造活性相関 II. 東京: 南江堂, 1982 .

4) Spencer PS, Schaumburg HH, Sabri MI, Veronesi B. The enlarging view of hexacarbon neurotoxicity. CRC Crit Rev Toxicol 1980; $7: 279-356$.

5) Spencer PS, Bischoff MC, Schaumburg HH. On the specific molecular configulation of neurotoxic aliphatic hexacarbon compounds causing centralperipheral distal axonopathy. Toxicol Appl Pharmacol 1978; $44: 17-28$.

6) O'Donoghue JL, Krasavage WJ. The structureactivity relationship of aliphatic diketones and their potential neurotoxicity. Toxicol Appl Pharmacol 1979; 48(part 2) : A55.

7) O'Donoghue JL, Krasavage WJ. Hexacarbon neuropathy : a $\gamma$-diketone neuropathy? J Neuropathol Exp Neurol 1979; $38: 333$.

8) Hansch C. (高木敬次郎監訳). ドラッグデザインKお 
ける定量的構造一活性椙関. Ariëns EJ, ed. ドラッグデ ザイン. 東京 : 広川䆵店, 1977 : 279-352.

9) Martin YC (江崎俊之訳). 定量薬物設計法. 東京：地 人䓊館, 1980.

10) Hansch C, Clayton JM. Lipophilic character and biological activity of drugs II : The parabolic case. J Pharm Sci 1973; 62:1-21.

11) Hansch C, Dunn III WJ. Linear relationships between lipophilic character and biological activity of drugs. J Pharm Sci 1972; 61 : 1-19.

12) Hansch C, Fujita T. $\rho-\sigma-\pi$-analysis: a method for the correlation of biological activity and chemical structure. J Am Chem Soc 1969; 86 : 1616-1626.

13) Fujita $T$, Iwasa J, Hansch C. A new substituent constant, $\pi$, derived from partition coefficients. J Am Chem Soc 1964; $86: 5175-5180$.

14) Jansson $K$, Jansson J. The toxicity of chlorophenols inV 79 Chinese hamster cells. Toxicol Lett 1993; $69: 289-294$.

15) Dillingham EO, Mast RW, Bass GE, Autian J. Toxicity of methyl- and halogen-substituted alcohols in tissue culture relative to structure-activity models and acute toxicity in mice. J Pharm Sci $1973 ; 62: 22-30$.

16) Yano E, Yoshioka M, Koizumi A. Relationship between chemical structure and cytotoxicity of aliphatic amines examined by a microtiter system with cultured fibroblasts. Jpn J Ind Health 1981; $23: 537-544$.

17) Harada A, Hanzawa M, Saito J, Hashimoto $K$. Quantitative analysis of structure-toxicity relationships of substituted anilines by use of $\mathrm{Balb} / 3 \mathrm{~T} 3$ cells. Environ Toxicol Chem 1992; 11 : 973-980.

18) Pauli W, Berger S, Kölen M, Gies A. Detecting membrane impairment caused by xenobiotics. Environ Toxicol Water Qual 1993; 8: 173-189.

19) Babich H, Borenfreund E. Structure-activity relationship (SAR) models established in vitro with the neutral red cytotoxicity assay. Toxicol In Vitro $1987 ; 1: 3-9$.

20) Jeppsson R. Parabolic relationship between lipophilicity and biological activity of aliphatic hydrocarbons, ethers and ketons after intravenous injections of emulsion formulations into mice. Acta Pharmacol Toxicol 1975; $37: 56-64$.

21) Tanii H, Tsuji H, Hashimoto K. Structuretoxicity relationship of monoketones. Toxicol Lett $1986 ; 30: 13-17$.

22) Tanii H, Hashimoto K. Structure-toxicity relationship of acrylates and methacrylates. Toxicol Lett $1982 ; 11: 125-129$.

23) Tanii H, Hashimoto K. Structure-acute toxicity relationship of dinitriles in mice. Arch Toxicol 1985; 57 : 88-93.

24) Tanii H, Saito S, Hashimoto K. Structuretoxicity relationship of ethylene glycol ethers. Arch Toxicol 1992; $66: 368-371$.

25) Tanii H, Hashimoto K. Studies on the mechanism of acute toxicity of nitriles in mice. Arch Toxicol $1984 ; 55: 47-54$.

26) Tanii $H$, Hashimoto $K$. Structure-toxicity relationship of aliphatic nitriles. Toxicol Lett 1984;
$22: 267-272$.

27) Grogan J, DeVito SC, Pearlman RS, Korzekwa KR. Modeling cyanide release from nitriles: prediction of cytochrome $\mathrm{P} 450$ mediated acute nitrile toxicity. Chem Res Toxicol 1992; 5 :548552.

28) Huang J, Tanii $H$, Ohyashiki $T$, Hashimoto $K$. Structure-toxicity relationship of monoketones : in vitro effects on beta-adrenergic receptor binding and $\mathrm{Na}^{+}-\mathrm{K}^{+}$-ATPase activity in mouse synaptosomes. Neurotoxicol Teratol 1993; $15: 345-352$.

29) Dunn III WJ, Hansch C. Chemicobiological interactions and the use of partition coefficients in their correlation. Chem Biol Interact 1974; $9: 75-$ 79.

30) Glave WR, Hansch C. Relationship between lipophilic character and anesthetic activity. J Pharm Sci 1972; 61 : 589-591.

31) Leo A, Hansch C, Church C. Comparison of parameters currently used in the study of structureactivity relationships. J Med Chem 1969; 12 : 766771.

32) Hansch C, Vittoria A, Silipo C, Jow PYC. Partition coefficients and structure-activity relationship of the anesthetic gases. J Med Chem 1975; 18: 546-548.

33) Franks NP, Lieb WR. Where do general anaesthetics act? Nature 1978; $274: 339-342$.

34) Janoff AS, Pringle MJ, Miller KW. Correlation of general anesthetic potency with solubility in membranes. Biochem Biophys Acta 1981; 649 : 125128.

35) Tsuruta H. Percutaneous absorption of organic solvents 1) comparative study of the in vivo percutaneous absorption of chlorinated solvents in mice. Ind Health $1975 ; 13: 227-236$.

36) Tsuruta H. Percutaneous absorption of organic solvents III. On the penetration rates of hydrophobic solvents through the excised rat skin. Ind Health $1982 ; 20: 335-345$.

37）鶴田 寛. 化学物質の経皮吸収之盇性一溶韵を中心と乙 て. 衛生化学 1986; $32: 229-241$.

38) Lien EJ, Tong GL. Physiochemical properties and percutaneous absorption of drugs. J Soc Cosmet Chem 1973; $24: 371-384$.

39) Cornford EM. Correlation between lipid partition coefficients and surface permeation in Schistosoma japonicum. J Membrane Biol 1982; 64 : 217224.

40) Roberts MS, Triggs EJ, Anderson RA. Permeability of solutes through biological membranes measured by a desorption technique. Nature 1975 ; $257: 225-227$.

41) Alarie Y. Sensory irritation by airborne chemicals. CRC Crit Rev Toxicol 1973; 2 : 299-363.

42) Engen T. Perception of odor and irritation. Environ Int $1986 ; 12: 177-187$.

43) Nielsen GD, Alarie Y. Animal assays for upper airway irritation. Screening of materials and structure-activity relations. Ann NY Acad Sci $1992 ; 641$ : 164-175.

44) Nielsen GD, Alarie $Y$. Sensor irritation, pul- 
monary irritation, and respiratory stimulation by airborne benzene and alkylbenzenes: prediction of safe industrial exposure levels and correlation with their thermodynamic properties. Toxicol Appl Pharmacol 1982; 65: 459-477.

45) Muller J, Greff G. Recherche de relations entre toxicite de molecules d'interet industriel et proprietes physico-chimiques: test d'irritation des voies aeriennes superieures applique a quatre familles chimiques. Fd Chem Toxicol 1984; 22: 661-664.

46) Roberts DW. QSAR for upper-respiratory tract irritation. Chem Biol Interact 1986; $57: 325-345$.

47) Abraham MH, Whiting GS, Alarie $Y$ et al. Hydrogen bonding 12. A new QSAR for upper respiratory tract irritation by airborne chemicals in mice. Quant Struct-Act Relat 1990; 9:6-10.

48) Schaper M. Development of a database for sensory irritants and its use in establishing occupational exposure level. Am Ind Hyg Assoc J 1993; $54 ; 488-544$.

49) Könemann H. Quantitative structure-activity relationships in fish toxicity studies. Toxicology $1981 ; 19: 209-221$.

50) Hermens J, Leeuwangh P, Musch A. Quantitative structure activity relationships and mixture toxicity studies of chloro- and alkylanilines at an acute lethal toxicity level to the guppy (Poecilia reticulata). Ecotoxicol Environ Safety 1984; 8 : 388394.

51) Hermens J, Busser $F$, Leeuwangh $P$, Musch A. Quantitative correlation studies between the acute lethal toxicity of 15 organic halides to the guppy (Poecilia reticulata) and chemical reactivity towards 4-nitrobenzylpyridine. Toxicol Environ Chem $1985 ; 9: 219-236$.

52) Deneer JW, Sinnige TL, Seinen W, Hermens JLM. Quantitative structure-activity relationships for the toxicity and bioconcentration factor of nitrobenzene derivatives towards the guppy (Poe- cilia reticulata). Aquat Toxicol $1987 ; 10: 115-129$.

53) Schultz TW, Moulton BA. Structure-activity relationships of selected pyridines I. Substituent constant analysis. Ecotoxicol Environ Safety 1985; $10: 97-111$.

54) Schultz TW, Riggin GW. Predictive correlations for the toxicity of alkyl-and halogen-substituted phenols. Toxicol Lett $1985 ; 25: 47-54$.

55) Call DJ, Brooke LT, Knuth ML, Poirier SH, Hoglund MD. Fish subchronic toxicity prediction model for industrial organic chemicals that produce narcosis. Environ Toxicol Chem 1985; 4: 335-341.

56) Schultz TW, Holcombe GW, Phipps GL. Relationships of quantitative structure-activity to com. parative toxicity of selected phenols in the pimephales promelas and tetrahymena pyriformis test systems. Ecotoxicol Environ Safety 1986; 12 : 146153.

57) Nendza M, Seydel JK. Quantitative structuretoxicity relationships for ecotoxicologically relevant biotestsystems and chemicals. Chemosphere $1988 ; 17: 1585-1602$.

58) Eder E, Henschler D, Neudecker T. Mutagenic properties of allylic and $\alpha, \beta$-unsaturated compounds: consideration of alkylating mechanisms. Xenobiotica $1982 ; 12: 831-848$.

59) Eder E, Neudecker T, Lutz D, Henschler D. Correlation of alkylating and mutagenic activities of allyl and allylic compounds : standard alkylation test vs. kenetic investigation. Chem Biol Interact $1982 ; 38: 308-315$.

60) Jones RB, Mackrodt WC. Structure-mutagenicity relationships for chlorinated ethylenes: a model based on the stability of the metabolically derived epoxides. Biochem Pharmacol 1982; 31: 3710-3713.

61) Jones RB, Mackrodt WC. Structure-genotoxicity relationship for aliphatic epoxides. Biochem Pharmacol $1983 ; 32: 2359-2362$.

著者への通信先 : 谷井秀治, 7920 石川県金沢市宝町 13-1 金沢大学医学部衛生学教室 Reprint requests to Department of Hygiene, School of Medicine, Kanazawa University, 13-1, Takaramachi, Kanazawa, 920 Japan (H. Tanii) 